\title{
Potential role of bacteria packaging by protozoa in the persistence and transmission of pathogenic bacteria
}

\author{
Alix M. Denoncourt ${ }^{1,2}$, Valérie E. Paquet ${ }^{1,2}$ and Steve J. Charette ${ }^{1,2,3 *}$ \\ 1 Institut de Biologie Intégrative et des Systèmes, Université Laval, Quebec City, QC, Canada \\ ${ }^{2}$ Centre de Recherche de I'Institut Universitaire de Cardiologie et de Pneumologie de Québec, Quebec City, QC, Canada \\ ${ }^{3}$ Département de Biochimie, de Microbiologie et de Bio-Informatique, Faculté des Sciences et de Génie, Université Laval, Quebec City, QC, Canada
}

Edited by:

Mickael Desvaux, INRA, France

Reviewed by:

O Roger Anderson, Lamont-Doherty

Earth Observatory of Columbia

University, USA

Stephan Schmitz-Esser, University

of Veterinary Medicine Vienna,

Austria

Thomas Hindré, University J.

Fourier, France

*Correspondence:

Steve J. Charette, Institut de

Biologie Intégrative et des

Systèmes, Université Laval, Pavillon

Charles-Eugène-Marchand,

1030 Avenue de la Médecine,

Quebec City, OC G1V OA6, Canada

e-mail:steve.charette@

bcm.ulaval.ca
Many pathogenic bacteria live in close association with protozoa. These unicellular eukaryotic microorganisms are ubiquitous in various environments. A number of protozoa such as amoebae and ciliates ingest pathogenic bacteria, package them usually in membrane structures, and then release them into the environment. Packaged bacteria are more resistant to various stresses and are more apt to survive than free bacteria. New evidence indicates that protozoa and not bacteria control the packaging process. It is possible that packaging is more common than suspected and may play a major role in the persistence and transmission of pathogenic bacteria. To confirm the role of packaging in the propagation of infections, it is vital that the molecular mechanisms governing the packaging of bacteria by protozoa be identified as well as elements related to the ecology of this process in order to determine whether packaging acts as a Trojan Horse.

Keywords: protozoa, multilamellar body, amoeba, bacteria packaging, Legionella pneumophila, mycobacteria, persistence, transmission

\section{INTRODUCTION}

The risk of the resurgence of bacterial infections caused by the decreasing effectiveness of antibiotics and the increasing number of people with weakened immune systems (cancer, AIDS, aging, etc.) require our attention (Croft et al., 2007). In this context, it is crucial that we improve our understanding of the behavior of pathogenic bacteria in various environments and their transmission in order to develop effective countermeasures. Since many protozoa interact with pathogenic bacteria in diverse environments, understanding the behavior of pathogens includes elucidating their relationships with protozoa.

Protozoa are unicellular eukaryotes that are ubiquitous in virtually all environments. Many are grazers that feed by ingesting other microorganisms, especially bacteria. Protozoa have been interacting with bacteria for a very long time, and several species have become hosts of pathogenic bacteria in natural environments and in man-made structures (air conditioning units, cooling towers, etc.). Studying these interactions is particularly important given that protozoa, for example amoebae, can serve as natural reservoirs for bacteria such as Legionella pneumophila and Mycobacterium spp. (Greub and Raoult, 2004). This represents a health risk since these bacteria can be dispersed into the air when aerosols are produced and can cause severe, even lethal, pneumonia when inhaled (Abu Kwaik et al., 1998; Falkinham, 2003; Philippe et al., 2006). L. pneumophila can be propagated over long distances (several kilometers) while remaining infectious (Nguyen et al., 2006; Nygard et al., 2008). In addition to L. pneumophila and Mycobacterium spp., a large number of bacterial species can withstand predation by protozoa and can persist and/or grow in them. A summary of the outcomes reported in the literature for pathogenic bacteria that interact with various protozoa is presented in Table 1. The interactions of pathogenic bacteria with protozoa can be advantageous if they can resist predation and digestion by the protozoa. For example, L. pneumophila has developed a clever strategy to protect itself from the enzymatic degradation that normally occurs in the endocytic pathway of the host by inducing the formation of replication vacuoles inside protozoa (Richards et al., 2013). By being able to grow and survive inside protozoa, these resistant bacteria are protected from stresses like biocides and antibiotics.

Some investigators have suggested that protozoa may act as a Trojan Horse in the propagation of human pathogenic bacteria (Barker and Brown, 1994; Greub and Raoult, 2004). For example, soon after L. pneumophila was discovered, it was suggested that bacteria residing inside amoebae, rather than free bacteria, were the source of legionellosis (Rowbotham, 1980). Legionella and mycobacteria associated with Acanthamoeba have a greater capability to replicate in macrophages than free bacteria (Cianciotto and Fields, 1992; Cirillo et al., 1994, 1997, 1999; Moffat et al., 1994; Neumeister et al., 2000). L. pneumophila, Mycobacterium spp., and other amoeba-resisting bacteria may also be able to reside within amoebal cysts (Steinert et al., 1998; MarcianoCabral and Cabral, 2003; Adekambi et al., 2006; El-Etr et al., 2009; Ben Salah and Drancourt, 2010). Most protozoa can make cysts, often with thick protective walls, which are their resting form, that provide protection from adverse environmental conditions (Greub and Raoult, 2004) and, at the same time, that provide involuntary protection to bacteria inside the cysts. Mycobacterium 
Table 1 | Fate of bacteria following interactions with protozoa.

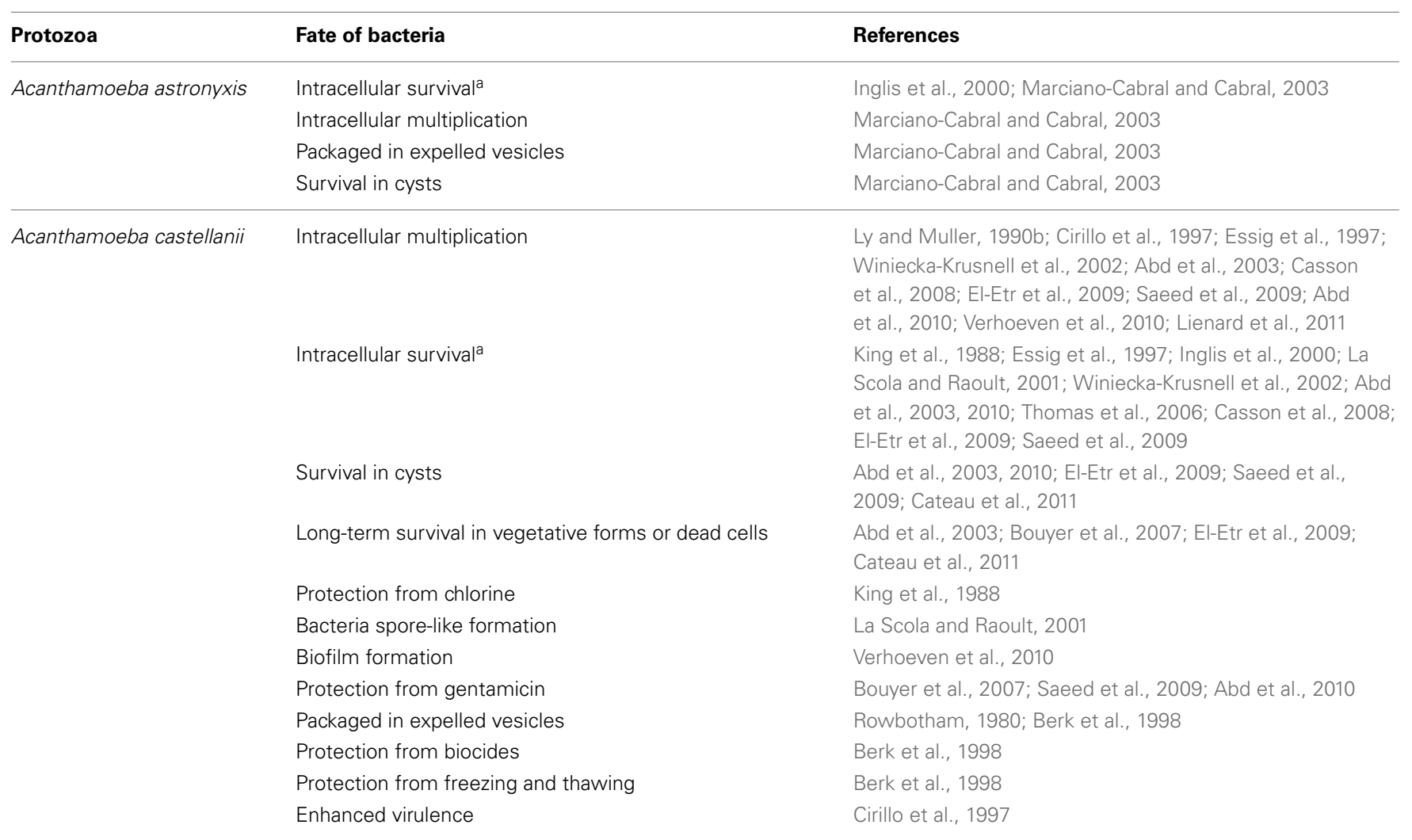

\begin{tabular}{lll}
\hline Acanthamoeba comandoni & Intracellular multiplication & Lienard et al., 2011 \\
\hline Acanthamoeba culbertsoni & Long-term survival in vegetative form & Cateau et al., 2011 \\
& Survival in cysts & Cateau et al., 2011 \\
\hline
\end{tabular}

Acanthamoeba polyphaga Intracellular multiplication

Kilvington and Price, 1990; Barker et al., 1999; La Scola and Raoult, 1999; Birtles et al., 2000; Ingham et al., 2000; Kahane et al., 2001; La Scola et al., 2004; Evstigneeva et al., 2009; Ben Salah and Drancourt, 2010; Lamrabet et al., 2012

Intracellular survival ${ }^{\mathrm{a}}$ Steinert et al., 1998; Barker et al., 1999; Horn et al., 1999; Ingham et al., 2000; Inglis et al., 2000; La Scola et al., 2000, 2001, 2002, 2003, 2004; Kahane et al., 2001; Adekambi et al., 2006; Medie et al., 2011; Lamrabet et al., 2012; Lamrabet and Drancourt, 2013

Survival in cysts

Kilvington and Price, 1990; Steinert et al., 1998; Horn et al., 1999; La Scola and Raoult, 1999; Kahane et al., 2001; Adekambi et al., 2006; Ben Salah and Drancourt, 2010; Medie et al., 2011

Packaged in expelled vesicles Berk et al., 1998

Protection from chlorine Kilvington and Price, 1990; La Scola and Raoult, 1999; Adekambi et al., 2006

Protection from biocides Berk et al., 1998

Protection from freezing and thawing

Berk et al., 1998

Protection from streptomycin and glutaraldehyde

Medie et al., 2011

\begin{tabular}{ll}
\hline Acanthamoeba spp. & Intracellular multiplication \\
& Intracellular survival
\end{tabular}

Survival in cysts

Michel and Hauroder, 1997; Tomov et al., 1999

Drozanski, 1956; Ly and Muller, 1990a; Drozanski, 1991; Amann et al., 1997; Fritsche et al., 1999; Marolda et al., 1999; Tomov et al., 1999; Horn et al., 2001, 2002

Horn et al., 2001, 2002 
Table 1 | Continued

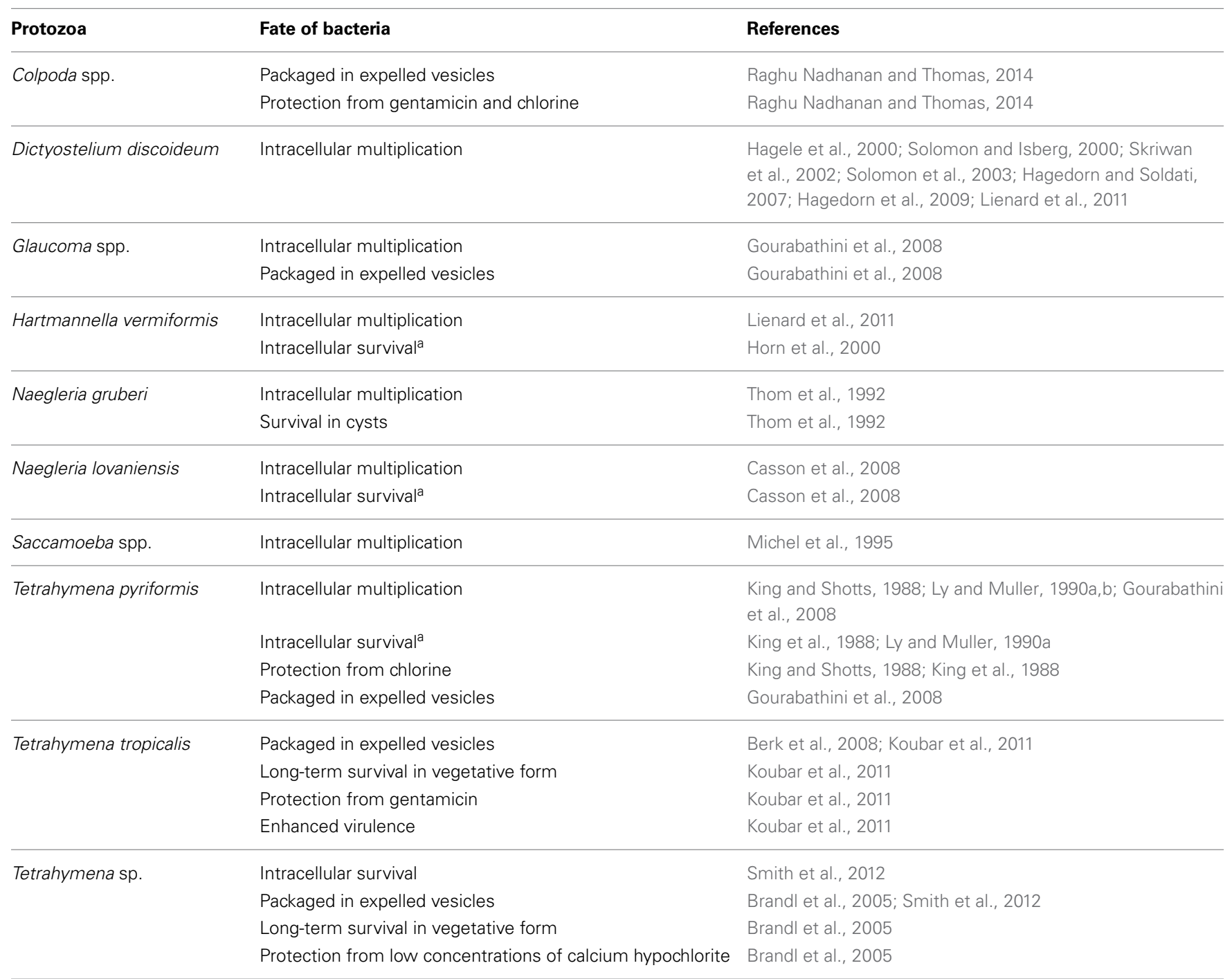

Positive outcomes for bacteria resulting from the interactions with protozoa are listed.

a In vacuoles or the cytoplasm.

spp. that reside inside cysts can resist $15 \mathrm{mg} / \mathrm{L}$ of free chlorine for $24 \mathrm{~h}$ (Adekambi et al., 2006). Protozoal cysts may thus be vectors for some bacteria (Ben Salah and Drancourt, 2010).

\section{BACTERIA PACKAGING BY PROTOZOA: A BACTERIAL CAMOUFLAGE}

A broad range of phagotrophic protists such as dinoflagellates, ciliates, and amoebae produce and expel vesicles as a part of their normal digestive process (Gezelius, 1959; Hohl, 1965; Allen and Wolf, 1974, 1979; Buck et al., 1990, 2005; Buck and Newton, 1995; Chekabab et al., 2012; Paquet et al., 2013). These expelled vesicles, which are often called fecal pellets or fecal balls, vary in composition, size, and morphology, depending on the protist and the trophic conditions. These pellets, which contain, among things, undigested particulates, and organic nutrients, may play significant roles in the flux of materials in the ecosphere (Buck et al., 1990).
In addition, the long co-evolution of protists and bacterial preys has given rise to survival strategies by the bacteria that enable them to avoid digestion in the normal phagocytic process and to be packaged in the egested pellets. Acanthamoeba and Tetrahymena protozoa parasitized by L. pneumophila expel vesicles or fecal pellets that contain viable bacteria (Figure 1) (Rowbotham, 1980; Berk et al., 1998, 2008; Koubar et al., 2011). While bacteria packaging was first observed with L. pneumophila, it might be a general phenomenon since a variety of protozoa that expel various species of bacteria packaged in vesicles have been reported (Table 2). Amoebae and ciliates appear to be the only two groups of protozoa known to produce extracellular vesicles containing bacteria so far (Table 2). The vesicles are produced in the endocytic pathway either on a regular basis or under certain specific conditions (see below). Bacteria that resist lysosomal digestion can be packaged in these structures and can then be expelled outside the cell by exocytosis or, in some cases, following 


\section{A}

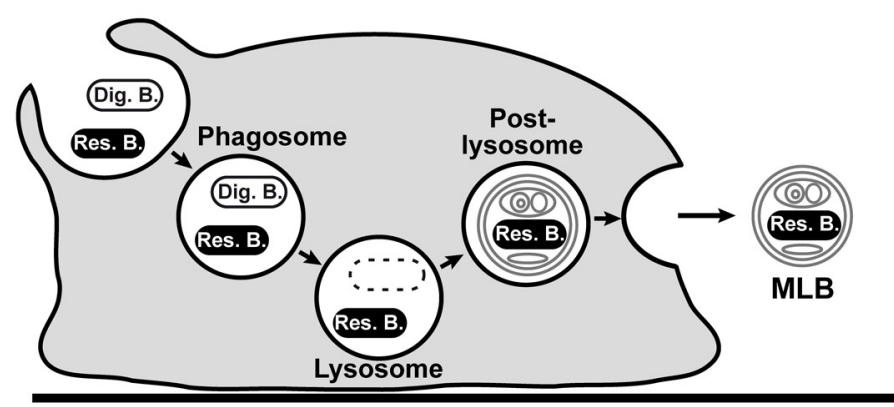

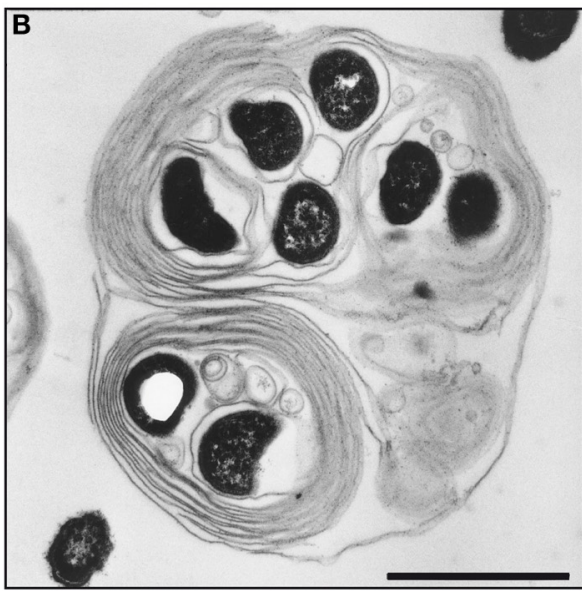

FIGURE 1 | Bacteria packaging by amoebae. (A) Schematic diagram of the packaging process that allows packaged bacteria to resist lysosomal degradation (Res. B), unlike digestible bacteria (Dig. B). The resisting bacteria are packaged in multilamellar bodies (MLB) and are then secreted by the amoebae. (B) Transmission electron microscopic image of L. pneumophila bacteria (black ovoid forms) packaged in a MLB produced and secreted by

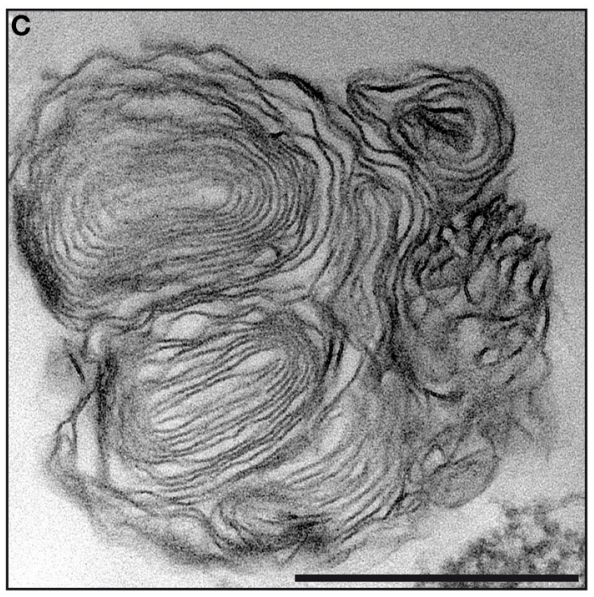

A. castellanii. Image reproduced from Berk et al. (1998) with the permission of the American Society for Microbiology. (C) Transmission electron microscopic image of a MLB devoid of bacteria produced and secreted by D. discoideum DH1-10 (Cornillon et al., 2000) grown on digestible bacteria, which were a laboratory strain of $K$. aerogenes (Benghezal et al., 2006). Scale bar $=1 \mu \mathrm{m}$ in $(\mathbf{B}, \mathbf{C})$ bacteria-dependent cell lysis (Figure 1) (Abd et al., 2003; Brandl et al., 2005; Gourabathini et al., 2008).

Packaged bacteria are protected against harsh conditions such as freezing and thawing, chlorine, and the biocides used in cooling towers (Berk et al., 1998; Brandl et al., 2005). Tetrahymena tropicalis-packaged L. pneumophila display greater gentamicin resistance and long-term survival in nutrient-poor environments, and are more infectious than free bacteria in cultured human pneumocyte cells (Koubar et al., 2011). More recently, it has been reported that viable Listeria monocytogenes can be enclosed in fecal pellets produced by Colpoda spp. (a ciliate) and that this results in gentamicin and sodium hypochlorite resistance of the bacteria (Raghu Nadhanan and Thomas, 2014). Packaging may thus be a way for the bacteria to persist in the environment. In fact, bacteria packaged by protozoa are more likely to propagate bacterial infections than bacteria-containing cysts. Packaged bacteria are probably the most frequent form of pathogenic bacteria associated with protozoa. Exocytosis is a continuous active process for grazing protozoa and hundreds of bacteria-containing vesicles can be expelled by a single protozoal cell (Berk et al., 1998; Brandl et al., 2005; Gourabathini et al., 2008). However, protozoal cells can form only a single bacteria-containing cyst and while bacteria have been observed in protozoal cysts, they are not always viable in these structures (Gourabathini et al., 2008).

Packages containing bacteria range in size from 2 to $6 \mu \mathrm{m}$ in diameter (Berk et al., 1998, 2008) and are smaller than vegetative forms of protozoa and even cysts, which can reach diameters of 10-20 $\mu \mathrm{m}$ (Nilsson, 2005). Given that respirable particles (i.e., those able to penetrate into the alveoli) must be under $3.5 \mu \mathrm{m}$ in diameter (Macher, 1999), packaged bacteria can thus penetrate deeper into the respiratory tract and the alveoli. Respiratory pathogens such as L. pneumophila that can be packaged are thus more likely to cause respiratory infections in this form than when included in vegetative forms of protozoa or cysts (Berk et al., 1998). It has been proposed that bacteria that develop inside amoebae may be responsible for some of the 50\% of lower respiratory tract infections with unexplained etiologies (Lamoth and Greub, 2009). While the packaging process needs to be studied in greater detail, it cannot be excluded that packaged bacteria may cause some of these lower respiratory tract infections.

\section{BACTERIA PACKAGING: A PROTOZOA-DRIVEN PROCESS}

The packages produced by amoebae (Figure 1B) and, to a lesser extent by ciliates (see below), are multilamellar bodies (MLBs) 
Table 2 | List of bacteria-protozoa combinations where bacteria packaging has been observed.

\begin{tabular}{|c|c|c|c|}
\hline Bacterium & Protozoa & Output & References \\
\hline \multirow[t]{2}{*}{ Escherichia coli 0157} & $\begin{array}{l}\text { Glaucoma spp. } \\
\text { Tetrahymena pyriformis }\end{array}$ & $\begin{array}{l}\text { Packaged in expelled vesicles, multiplication, and } \\
\text { escape from the vesicles }\end{array}$ & Gourabathini et al., 2008 \\
\hline & Tetrahymena sp. & Intracellular survival, packaged in expelled vesicles & Smith et al., 2012 \\
\hline Helicobacter pylori & Acanthamoeba astronyxis & $\begin{array}{l}\text { Packaged in expelled vesicles, intracellular } \\
\text { multiplication }\end{array}$ & Marciano-Cabral and Cabral, 2003 \\
\hline \multirow[t]{3}{*}{ Legionella pneumophila } & $\begin{array}{l}\text { Acanthamoeba castellanii } \\
\text { Acanthamoeba polyphaga }\end{array}$ & $\begin{array}{l}\text { Packaged in expelled vesicles, resistance to } \\
\text { biocides and freezing and thawing }\end{array}$ & Berk et al., 1998 \\
\hline & Tetrahymena tropicalis & Packaged in expelled vesicles & Berk et al., 2008 \\
\hline & & $\begin{array}{l}\text { Packaged in expelled vesicles, long-term survival, } \\
\text { gentamicin resistance, increased infectivity }\end{array}$ & Koubar et al., 2011 \\
\hline \multirow[t]{2}{*}{ Salmonella enterica } & $\begin{array}{l}\text { Glaucoma sp. } \\
\text { Tetrahymena pyriformis }\end{array}$ & Packaged in expelled vesicles & Gourabathini et al., 2008 \\
\hline & Tetrahymena sp. & $\begin{array}{l}\text { Packaged in expelled vesicles, enhanced survival, } \\
\text { resistance to low concentrations of calcium } \\
\text { hypochlorite }\end{array}$ & Brandl et al., 2005 \\
\hline
\end{tabular}

formed of several concentric layers of lipid membranes containing viable bacteria. MLBs devoid of viable bacteria are also produced (Figure 1C), for example by Acanthamoeba castellanii (Chekabab et al., 2012), and have been extensively studied using Dictyostelium discoideum amoeba (Gezelius, 1959; Mercer and Shaffer, 1960; Gezelius, 1961; Hohl, 1965; Barondes et al., 1985; Cooper et al., 1986; Fukuzawa and Ochiai, 1993; Emslie et al., 1998; Marchetti et al., 2004; Paquet et al., 2013).

To date, the production of MLBs by $D$. discoideum has only been studied in the presence of digestible bacteria (i.e., bacteria that are degraded by the lysosomal enzymes of the endocytic pathway) and not in the presence of undigestible pathogenic bacteria. Interestingly, since $D$. discoideum cells grown in liquid medium in the absence of bacteria produce virtually no MLB (Mercer and Shaffer, 1960; Hohl, 1965; Marchetti et al., 2004; Paquet et al., 2013), it was considered that these MLBs were undigested bacterial remains. However, new evidence has shown that MLB production by $D$. discoideum depends largely on the metabolism of the protozoa even if the presence of digestible bacteria is required to produce MLBs. The analysis of the composition of purified $D$. discoideum MLBs revealed that the lipids in these structures are amoebal in origin, that is, they are mainly produced via amoebal metabolic pathways, even if they are only produced when the amoebae are fed Klebsiella aerogenes, a digestible bacterium (Paquet et al., 2013). Even if bacterial remains (glycoconjugates) have also been detected in D. discoideum MLBs (Cooper et al., 1986), the lipid composition of these structures suggests that they are not strictly fecal pellets used to dispose of undigested bacterial constituents and that they may play significant roles in amoebal physiology.
The fact that the lipids in the MLBs are amoebal in origin is an argument in favor of the idea that bacteria packaging is under the control of protozoa. However, when D. discoideum cells are fed digestible Gram-positive bacteria (Figure 2) compared to digestible Gram-negative bacteria (Figure 1), the type of food, that is, the type of bacteria ingested, can affect the morphology of the MLBs. Those produced and secreted by D. discoideum cells grown on Bacillus subtilis and Micrococcus luteus (Grampositive bacteria) are quite different than those from amoebae grown on $K$. aerogenes (Gram-negative bacterium). In the presence of $B$. subtilis, the MLBs have a more heterogeneous structure (Figures 2A,B) that can be composed of concentric membrane lamellae, clusters of vesicles in one structure, or a mix of the two. MLBs produced and secreted by cells grown on M. luteus contain fewer lamellae and often have a broken appearance (Figure 2C). Without being the main actor in bacteria packaging, internalized bacteria may produce factors that influence the process. For example, L. pneumophila LepA and LepB proteins appear to be essential for the specific non-lytic release of the bacteria from amoebae (Chen et al., 2004). Do these proteins act as a kind of regulator of the packaging process or only of the exocytosis function? Additional studies are required to evaluate the contribution of bacterial factors to the packaging process.

Less is known about the nature of the packages produced by ciliates than those produced by amoebae. The composition and structure of the packages or pellets produced by ciliates such as Tetrahymena spp. differ from those of amoebal MLBs. Packaged bacteria secreted by Tetrahymena spp. appear to have various profiles as shown by a transmission electron microscopy study of pellets containing L. pneumophila (Berk et al., 2008). The pellets had 

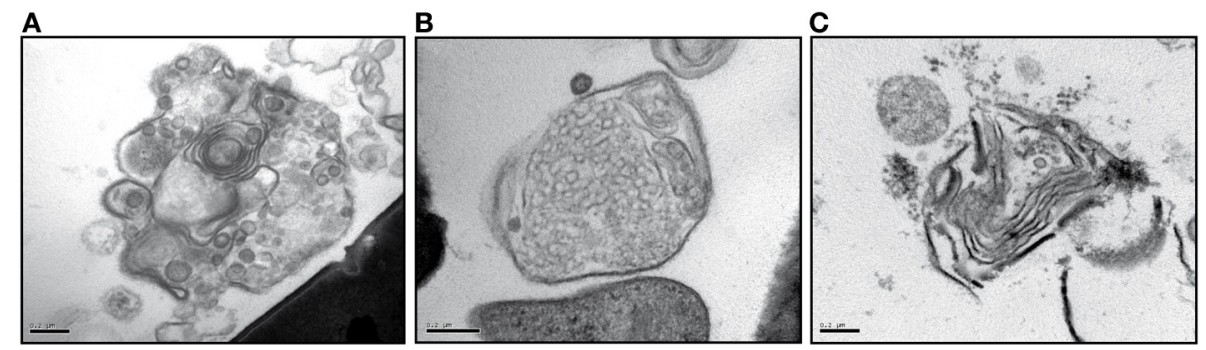

FIGURE 2 | MLBs secreted by $D$. discoideum cells grown on Gram-positive bacteria. Transmission electron microscopic images of MLBs secreted by D. discoideum DH1-10 cells (Cornillon et al., 2000) grown on B. subtilis (Benghezal et al., 2006) (A,B) and M. luteus ATCC 4698 (C). One MLB is shown in each panel. Scale bars = $0.2 \mu \mathrm{m}$. three morphologies: (1) bacteria embedded in abundant membranous and vesicular material reminiscent of amoebal MLBs, (2) bacteria surrounded by amorphous material, and (3) bacteria with no apparent electron dense material surrounding them. Tetrahymena spp. have also been induced to package Escherichia coli O157:H7 (Smith et al., 2012). Scanning electron microscopy has revealed that the pellets produced in this case have a net-like structure surrounding the bacteria and aggregate in flocs due to their stickiness. This suggests that packages produced by ciliates can vary in form and composition as with amoebae. However, it is difficult to determine the extent of the variability without an exhaustive side-by-side comparison of packages produced by various protozoa packaging the same bacterial species.

Like amoeba, ciliates are able to produce MLBs when fed digestible bacteria (Berk et al., 2008). These MLBs are identical to those produced by $D$. discoideum fed digestible bacteria. This suggests that ciliates also control the production of pellets. Immunolabeling has shown that the membranous material in packages produced by Tetrahymena spp. is, in part, of bacterial origin (Berk et al., 2008), and indicates that pellets produced by ciliates are likely a mosaic composed of protozoal and bacterial material similar to MLBs produced by amoebae.

The most convincing proof that bacteria packaging is a protozoa-driven process comes from experiments where protozoa are fed synthetic beads. Since the primary characteristic of pathogenic bacterial parasites of protozoa is resistance to enzymatic degradation in phago-lysosomes (Molmeret et al., 2005), the synthetic beads mimic undigestible bacteria but are inert and do not biochemically interact with the protozoa. When fed latex beads, Tetrahymena cells produced packaged beads in a net-like matrix similar to that observed with E. coli (Smith et al., 2012). Similarly, D. discoideum cells grown in presence of polystyrene beads and digestible bacteria produced MLBs containing beads (Figure 3). These results are of the utmost important since they indicate that the packaging process is independent of the ingested particle and is mainly under the control of the protozoa as long as the production of packages is metabolically stimulated.

\section{HYPOTHESIS AND PERSPECTIVES}

Since packages can be produced in abundance by protozoa and provide bacteria enclosed in the structures with much greater resistance to unfavorable conditions, it is tempting to hypothesize
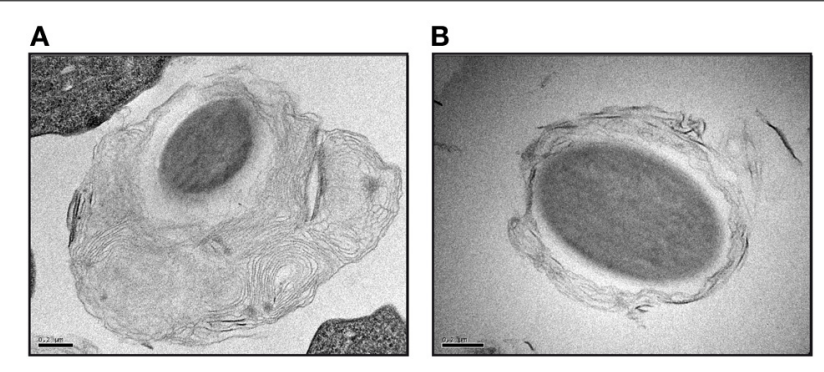

FIGURE 3 | D. discoideum cells can package polystyrene beads in secreted MLBs. Transmission electronic micrographic images of polystyrene beads packaged in thick (A) and thin (B) MLBs after being incubated with D. discoideum DH1-10 cells (Cornillon et al., 2000) in the presence of digestible bacteria. Scale bars $=0.2 \mu \mathrm{m}$.

that bacteria packaging by protozoa is a general process that contributes to the survival and propagation of pathogenic bacteria in the environment. This process may be an unsuspected source of pathogenic bacteria that could explain many infections, including some of the respiratory tract. The conditions that favor the production of packaged bacteria and their distribution in natural environments and man-made structures are unknown. It will be necessary to identify the environments and conditions in which packaged bacteria are produced in the real world. This cannot be achieved without conducting field studies to first check for the presence of protozoa harboring intracellular bacteria and then to quantitatively assess the presence of packaged bacteria. This information will help in the development of strategies to prevent the spread of pathogenic bacteria. To confirm this hypothesis, many elements need to be addressed.

First, it could be interesting to determine whether other players are involved in bacteria packaging. Even if many protozoa and bacteria are known to participate in this process (Table 2), it would be interesting to determine how many other pathogenic and even non-pathogenic bacteria can be packaged as well as which protozoa can perform the packaging. This may be quite difficult since some environments in which bacteria packaging may occur cannot be easily reproduced in vitro. In addition, some bacterial species may be packaged by one type of protozoa but not by another. Bacteria packaging may also occur only in presence of a tripartite interaction as with $D$. discoideum where digestible 
bacteria are required to produce MLBs containing synthetic beads (Figure 4) and with A. castellanii, where the production of packaged L. pneumophila is enhanced in the presence of digestible E. coli (Berk et al., 1998). Environmental conditions likely play a role in the yield of packaged bacteria and even in the process itself. For example, the resistance of L. pneumophila to Acanthamoeba palestinensis predation can be modulated by environmental conditions such as the incubation temperature (Anand et al., 1983), which may affect the capacity of the bacteria to be included in packages.

Nothing is known about the protozoal mechanisms involved in bacteria packaging since research to date has mainly focused on the impacts of packaging on the bacteria. Apart from the advantages packaging provides to bacteria (Table 2), research has also focused on the transcriptional response of Salmonella enterica during packaging and the requirement of L. pneumophila for a functional Dot/Icm system to resist protozoal degradation and be packaged (Berk et al., 2008; Rehfuss et al., 2011). However, given that the packaging process is under the control of protozoa, a better understanding of the molecular mechanisms of the protozoal endocytic pathway involved in the packaging process is required.

MLB production by $D$. discoideum cells grown in liquid culture can be stimulated by U18666A, a drug that disrupts intracellular cholesterol transport and metabolism in mammalian cells. Under these conditions, MLBs are produced by the invagination of the membrane inside the lysosomal compartments (Marchetti et al., 2004). Inward budding also occurs when D. discoideum cells are fed digestible bacteria (Figure 4), suggesting that lysosomal membrane proteins may be included in MLBs. In fact, amoebal proteins such cysteine proteinase and discoidin I as well as other unidentified glycosylated proteins have been already detected in secreted MLBs (Barondes et al., 1985; Fukuzawa and Ochiai, 1993; Emslie et al., 1998; Paquet et al., 2013).

The identification of all the protozoal proteins in the MLBs used to package bacteria as well as the biological machinery
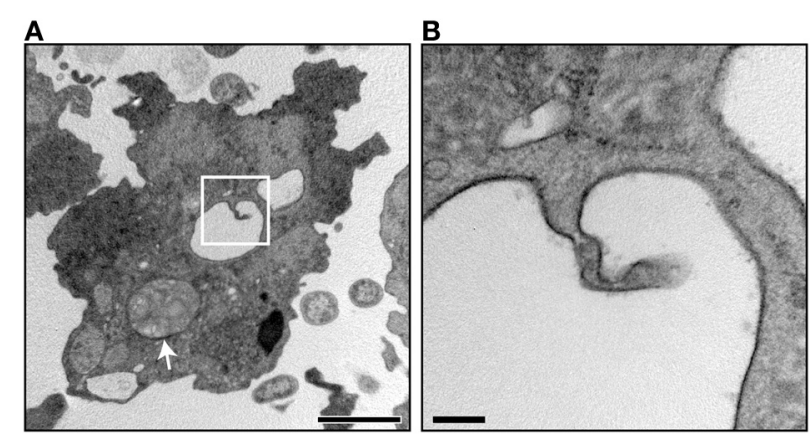

FIGURE 4 | Intra-lysosomal profile of $D$. discoideum cells fed digestible bacteria. (A) Transmission electronic micrographic image of a D. discoideum DH1-10 cell (Cornillon et al., 2000) with a Iysosomal compartment displaying an intra-lysosomal profile (white square) and a MLB inside a lysosomal compartment (white arrow). B. Magnification of image A showing the inward bud in greater detail. The inward budding is in a lysosomal compartment containing no other electron dense material. The invaginations of the lysosomal membrane are hard to detect in compartments already containing MLBs because the compartments are too crowded. Scale bar $=2 \mu \mathrm{m}$ in (A) and $0.2 \mu \mathrm{m}$ in (B). involved in the process and their characterization will open up new avenues for understanding the packaging process. For example, the identification of the proteins included in MLBs will provide cues to the packaging mechanisms as well as markers for visualizing the packaging process by real-time microscopy. The identification of these proteins and mechanisms will make it possible to develop tools that will help to address important research issues related to bacteria packaging by protozoa such as their presence in the environment and their role in infectious diseases. Understanding the mechanisms should also make it possible to develop chemical inhibitors or modulators of bacteria packaging.

In addition to identifying protozoal proteins in the packages, another approach to understand the mechanisms involved in the process would be to identify the proteins that are essential for the packaging process. Since the production of MLBs is similar to the production of multivesicular bodies (MVBs) by many eukaryotic organisms (Piper and Katzmann, 2007), it is highly likely that the ESCRT complexes involved in MVB biogenesis are also involved in the production of packaged bacteria. Among others, autophagy is probably also associated with MLB production since a link exists between autophagy and MVB biogenesis (Fader and Colombo, 2009).

The $D$. discoideum model appears to be promising for the identification of the genes encoding the proteins involved in the packaging process. Site-directed mutagenesis is a routine procedure with $D$. discoideum, and a mutant of tom 1 , which encodes one of the proteins of an ESCRT-like complex in this amoeba, has already been developed (Blanc et al., 2009). Mutants of the gene encoding Alix, a protein functionally associated with ESCRT complexes, as well as of genes encoding proteins involved in autophagy are also already available (Mattei et al., 2006; CalvoGarrido et al., 2010). Studying the capacity of these mutants and others that can be generated in the future to produce normal MLBs appears to be a good approach for shedding light on the mechanisms involved in bacteria packaging.

In addition to studying the mechanisms of package formation by protozoa, the impact of packaged bacteria on human health must be investigated. The most probable assumption is that packaged bacteria can be aerosolized, spread over long distances, and play a role in the transmission of respiratory tract infections. Since aerosolization is a major route of transmission of many human pathogens and is also a significant stress factor for microorganisms (Macher, 1999), it is important to determine the relative viability of packaged bacteria compared to free bacteria following aerosolization. It is also important to determine the response of aerosolized packaged bacteria to environmental stresses such as ultraviolet radiation (UV).

Previous studies have provided support for the idea that the intracellular growth of pathogenic bacteria in protozoal hosts increases the invasive potential and virulence of the bacteria in mammals (Cirillo et al., 1994, 1997, 1999; Molmeret et al., 2005). By producing packaged bacteria, protozoa may help bacteria to remain undetected by the immune system following inhalation, which in turn may help them to better adapt to their new environment like the respiratory tract and be more effective in the development of an infection. While the role of bacteria packaging in the infectious process has never been clearly addressed, 
T. tropicalis-packaged L. pneumophila are much more infectious than free bacteria in cultured human pneumocyte cells (Koubar et al., 2011). Are packaged bacteria more infectious than free bacteria in animal models? How does the immune system response to packaged and free bacteria differ? Answers to these questions are fundamental because protozoa can produce hundreds of packages containing pathogenic bacteria that can persist even after the protozoa have disappeared.

\section{CONCLUSION}

Research to date has been limited to descriptions of bacteria packaging by various protozoa. A number of findings suggest that packaging provides the bacteria with an advantage in the environment and can contribute to their pathogenicity. However, many elements need to be clarified to determine whether packaged bacteria are a significant source of infections.

It will be essential to extend the characterization of the role played by bacteria packaging to the persistence of pathogens in the environment and their ability to cause infections, especially of the respiratory tract. More precisely, we require a better understanding of the mechanisms involved in bacteria packaging, the magnitude of this phenomenon in various environments, the enhanced virulence potential related to the increased propagation of bacteria, and their ability to cause infections. The development of packaging markers, protocols for producing packaged bacteria, and methods to detect these bacteria are also needed to better understand this process. Ultimately, if bacteria packaging appears to make an important contribution to the persistence and transmission of pathogenic bacteria, it will be possible to reduce their infectivity and propagation by modulating their interactions with protozoa.

\section{ACKNOWLEDGMENTS}

We thank F. Letourneur (Université Montpellier II, France) for critical reading of the manuscript. We are grateful to $\mathrm{R}$. Janvier (Electronic Microscopy Platform, IBIS) for technical assistance. The work related to this manuscript was funded by a grants from the Chaire de Pneumologie de la Fondation J.-D. Beìgin of Universiteì Laval and the Fonds Alphonse L'Espeìrance of the Fondation de l'IUCPQ, and an Establishment of Young Researchers-Junior 1 grant from the Fonds de la Recherche du Queìbec en Santeì (FRQS).

\section{REFERENCES}

Abd, H., Johansson, T., Golovliov, I., Sandstrom, G., and Forsman, M. (2003). Survival and growth of Francisella tularensis in Acanthamoeba castellanii. Appl. Environ. Microbiol. 69, 600-606. doi: 10.1128/AEM.69.1.600-606.2003

Abd, H., Valeru, S. P., Sami, S. M., Saeed, A., Raychaudhuri, S., and Sandstrom, G. (2010). Interaction between Vibrio mimicus and Acanthamoeba castellanii. Environ. Microbiol. Rep. 2, 166-171. doi: 10.1111/j.1758-2229.2009.00129.x

Abu Kwaik, Y., Gao, L. Y., Stone, B. J., Venkataraman, C., and Harb, O. S. (1998). Invasion of protozoa by Legionella pneumophila and its role in bacterial ecology and pathogenesis. Appl. Environ. Microbiol. 64, 3127-3133.

Adekambi, T., Ben Salah, S., Khlif, M., Raoult, D., and Drancourt, M. (2006). Survival of environmental mycobacteria in Acanthamoeba polyphaga. Appl. Environ. Microbiol. 72, 5974-5981. doi: 10.1128/AEM.03 075-05

Allen, R. D., and Wolf, R. W. (1974). The cytoproct of Paramecium caudatum: structure and function, microtubules, and fate of food vacuole membranes. J. Cell Sci. $14,611-631$
Allen, R. D., and Wolf, R. W. (1979). Membrane recycling at the cytoproct of Tetrahymena. J. Cell Sci. 35, 217-227.

Amann, R., Springer, N., Schonhuber, W., Ludwig, W., Schmid, E. N., Muller, K. D., et al. (1997). Obligate intracellular bacterial parasites of Acanthamoebae related to Chlamydia spp. Appl. Environ. Microbiol. 63, 115-121.

Anand, C. M., Skinner, A. R., Malic, A., and Kurtz, J. B. (1983). Interaction of $L$. pneumophilia and a free living amoeba (Acanthamoeba palestinensis). J. Hyg. 91, 167-178. doi: 10.1017/S0022172400060174

Barker, J., and Brown, M. R. (1994). Trojan horses of the microbial world: protozoa and the survival of bacterial pathogens in the environment. Microbiology 140 (pt 6), 1253-1259. doi: 10.1099/00221287-140-6-1253

Barker, J., Humphrey, T. J., and Brown, M. W. (1999). Survival of Escherichia coli O157 in a soil protozoan: implications for disease. FEMS Microbiol. Lett. 173, 291-295. doi: 10.1111/j.1574-6968.1999.tb13516.x

Barondes, S. H., Haywood-Reid, P. L., and Cooper, D. N. (1985). Discoidin I, an endogenous lectin, is externalized from Dictyostelium discoideum in multilamellar bodies. J. Cell Biol. 100, 1825-1833. doi: 10.1083/jcb.100.6.1825

Benghezal, M., Fauvarque, M. O., Tournebize, R., Froquet, R., Marchetti, A., Bergeret, E., et al. (2006). Specific host genes required for the killing of Klebsiella bacteria by phagocytes. Cell. Microbiol. 8, 139-148. doi: 10.1111/j.14625822.2005.00607.x

Ben Salah, I., and Drancourt, M. (2010). Surviving within the amoebal exocyst: the Mycobacterium avium complex paradigm. BMC Microbiol. 10:99. doi: 10.1186/1471-2180-10-99

Berk, S. G., Faulkner, G., Garduno, E., Joy, M. C., Ortiz-Jimenez, M. A., and Garduno, R. A. (2008). Packaging of live Legionella pneumophila into pellets expelled by Tetrahymena spp. does not require bacterial replication and depends on a dot/Icm-mediated survival mechanism. Appl. Environ. Microbiol. 74, 2187-2199. doi: 10.1128/AEM.01214-07

Berk, S. G., Ting, R. S., Turner, G. W., and Ashburn, R. J. (1998). Production of respirable vesicles containing live Legionella pneumophila cells by two Acanthamoeba spp. Appl. Environ. Microbiol. 64, 279-286.

Birtles, R. J., Rowbotham, T. J., Michel, R., Pitcher, D. G., Lascola, B., AlexiouDaniel, S., et al. (2000). 'Candidatus Odyssella thessalonicensis' gen. nov., sp. nov., an obligate intracellular parasite of Acanthamoeba species. Int. J. Syst. Evol. Microbiol. 50(pt 1), 63-72. doi: 10.1099/00207713-50-1-63

Blanc, C., Charette, S. J., Mattei, S., Aubry, L., Smith, E. W., Cosson, P., et al. (2009). Dictyostelium Tom1 participates to an ancestral ESCRT-0 complex. Traffic 10, 161-171. doi: 10.1111/j.1600-0854.2008.00855.x

Bouyer, S., Imbert, C., Rodier, M. H., and Hechard, Y. (2007). Long-term survival of Legionella pneumophila associated with Acanthamoeba castellanii vesicles. Environ. Microbiol. 9, 1341-1344. doi: 10.1111/j.1462-2920.2006.01229.x

Brandl, M. T., Rosenthal, B. M., Haxo, A. F., and Berk, S. G. (2005). Enhanced survival of Salmonella enterica in vesicles released by a soilborne Tetrahymena species. Appl. Environ. Microbiol. 71, 1562-1569. doi: 10.1128/AEM.71.3.15621569.2005

Buck, K., Bolt, P., and Garrison, D. (1990). Phagotrophy and fecal pellet production by an athecate dinoflagellate in Antarctic sea ice. Mar. Ecol. Prog. Ser. 60, 75-84. doi: 10.3354/meps060075

Buck, K., Marin, R., and Chavez, F. (2005). Heterotrophic dinoflagellate fecal pellet production: grazing of large, chain-forming diatoms during upwelling events in Monterey Bay, California. Aquat. Microb. Ecol. 40, 293-298. doi: 10.3354/ame040293

Buck, K., and Newton, J. (1995). Fecal pellet flux in Dabob Bay during a diatom bloom: contribution of microzooplankton. Limnol. Oceanogr. 40, 306-315. doi: 10.4319/lo.1995.40.2.0306

Calvo-Garrido, J., Carilla-Latorre, S., Kubohara, Y., Santos-Rodrigo, N., Mesquita, A., Soldati, T., et al. (2010). Autophagy in Dictyostelium: genes and pathways, cell death and infection. Autophagy 6, 686-701. doi: 10.4161/auto.6.6.12513

Casson, N., Michel, R., Muller, K. D., Aubert, J. D., and Greub, G. (2008) Protochlamydia naegleriophila as etiologic agent of pneumonia. Emerging Infect. Dis. 14, 168-172. doi: 10.3201/eid1401.070980

Cateau, E., Verdon, J., Fernandez, B., Hechard, Y., and Rodier, M. H. (2011) Acanthamoeba sp. promotes the survival and growth of Acinetobacter baumanii. FEMS Microbiol. Lett. 319, 19-25. doi: 10.1111/j.1574-6968.2011.02261.x

Chekabab, S. M., Daigle, F., Charette, S. J., Dozois, C. M., and Harel, J. (2012). Survival of enterohemorrhagic Escherichia coli in the presence of Acanthamoeba castellanii and its dependence on Pho regulon. Microbiologyopen 1, 427-437. doi: $10.1002 / \mathrm{mbo} 3.40$ 
Chen, J., De Felipe, K. S., Clarke, M., Lu, H., Anderson, O. R., Segal, G., et al. (2004). Legionella effectors that promote nonlytic release from protozoa. Science 303 1358-1361. doi: 10.1126/science.1094226

Cianciotto, N. P., and Fields, B. S. (1992). Legionella pneumophila mip gene potentiates intracellular infection of protozoa and human macrophages. Proc. Natl. Acad. Sci. U.S.A. 89, 5188-5191. doi: 10.1073/pnas.89.11.5188

Cirillo, J. D., Cirillo, S. L., Yan, L., Bermudez, L. E., Falkow, S., and Tompkins, L. S. (1999). Intracellular growth in Acanthamoeba castellanii affects monocyte entry mechanisms and enhances virulence of Legionella pneumophila. Infect. Immun. 67, 4427-4434.

Cirillo, J. D., Falkow, S., and Tompkins, L. S. (1994). Growth of Legionella pneumophila in Acanthamoeba castellanii enhances invasion. Infect. Immun. 62, 3254-3261.

Cirillo, J. D., Falkow, S., Tompkins, L. S., and Bermudez, L. E. (1997). Interaction of Mycobacterium avium with environmental amoebae enhances virulence. Infect. Immun. 65, 3759-3767.

Cooper, D. N. W., Haywoodreid, P. L., Springer, W. R., and Barondes, S. H. (1986) Bacterial glycoconjugates are natural ligands for the carbohydrate binding-site of discoidin-I and influence its cellular compartimentalization. Dev. Biol. 114, 416-425. doi: 10.1016/0012-1606(86)90206-X

Cornillon, S., Pech, E., Benghezal, M., Ravanel, K., Gaynor, E., Letourneur, F., et al. (2000). Phglp is a nine-transmembrane protein superfamily member involved in Dictyostelium adhesion and phagocytosis. J. Biol. Chem. 275, 34287-34292. doi: 10.1074/jbc.M006725200

Croft, A. C., D'antoni, A. V., and Terzulli, S. L. (2007). Update on the antibacterial resistance crisis. Med. Sci. Monit. 13, RA103-RA118.

Drozanski, W. (1956). Fatal bacterial infection in soil amoebae. Acta Microbiol. Pol. 5, 315-317.

Drozanski, W. J. (1991). Sarcobium-Lyticum gen-nov, sp-nov, an obligate intracellular bacterial parasite of small free-living amebas. Int. J. Syst. Bacteriol. 41, 82-87. doi: 10.1099/00207713-41-1-82

El-Etr, S. H., Margolis, J. J., Monack, D., Robison, R. A., Cohen, M., Moore, E., et al. (2009). Francisella tularensis type A strains cause the rapid encystment of Acanthamoeba castellanii and survive in amoebal cysts for three weeks postinfection. Appl. Environ. Microbiol. 75, 7488-7500. doi: 10.1128/AEM.01829-09

Emslie, K. R., Birch, D., Champion, A. C., and Williams, K. L. (1998). Localisation of glycoproteins containing type 3 O-linked glycosylation to multilamellar bodies in Dictyostelium discoideum. Eur. J. Protistol. 34, 321-328. doi: 10.1016/S0932-4739(98)80059-X

Essig, A., Heinemann, M., Simnacher, U., and Marre, R. (1997). Infection of Acanthamoeba castellanii by Chlamydia pneumoniae. Appl. Environ. Microbiol. $63,1396-1399$

Evstigneeva, A., Raoult, D., Karpachevskiy, L., and La Scola, B. (2009). Amoeba co-culture of soil specimens recovered 33 different bacteria, including four new species and Streptococcus pneumoniae. Microbiology 155, 657-664. doi: 10.1099/mic.0.022970-0

Fader, C. M., and Colombo, M. I. (2009). Autophagy and multivesicular bodies: two closely related partners. Cell Death Differ. 16, 70-78. doi: 10.1038/cdd.2008.168

Falkinham, J. O. 3rd. (2003). Mycobacterial aerosols and respiratory disease. Emerging Infect. Dis. 9, 763-767. doi: 10.3201/eid0907. 020415

Fritsche, T. R., Horn, M., Seyedirashti, S., Gautom, R. K., Schleifer, K. H., and Wagner, M. (1999). In situ detection of novel bacterial endosymbionts of Acanthamoeba spp. phylogenetically related to members of the order Rickettsiales. Appl. Environ. Microbiol. 65, 206-212.

Fukuzawa, M., and Ochiai, H. (1993). Different subcellular localizations of discoidin I monomer and tetramer in Dictyostelium discoideum cells: using conformation-specific monoclonal antibodies. Exp. Cell Res. 204, 61-72. doi: 10.1006/excr.1993.1009

Gezelius, K. (1959). The ultrastructure of cells and cellulose membranes in Acrasiae. Exp. Cell Res. 18, 425-453. doi: 10.1016/0014-4827(59)90310-6

Gezelius, K. (1961). Further studies in the ultrastructure of Acrasiae. Exp. Cell Res. 23, 300-310. doi: 10.1016/0014-4827(61)90039-8

Gourabathini, P., Brandl, M. T., Redding, K. S., Gunderson, J. H., and Berk, S. G. (2008). Interactions between food-borne pathogens and protozoa isolated from lettuce and spinach. Appl. Environ. Microbiol. 74, 2518-2525. doi 10.1128/AEM.02709-07

Greub, G., and Raoult, D. (2004). Microorganisms resistant to free-living amoebae. Clin. Microbiol. Rev. 17, 413-433. doi: 10.1128/CMR.17.2.413-433.2004
Hagedorn, M., Rohde, K. H., Russell, D. G., and Soldati, T. (2009). Infection by tubercular mycobacteria is spread by nonlytic ejection from their amoeba hosts. Science 323, 1729-1733. doi: 10.1126/science.1169381

Hagedorn, M., and Soldati, T. (2007). Flotillin and $\mathrm{RacH}$ modulate the intracellular immunity of Dictyostelium to Mycobacterium marinum infection. Cell. Microbiol. 9, 2716-2733. doi: 10.1111/j.1462-5822.2007. 00993.x

Hagele, S., Kohler, R., Merkert, H., Schleicher, M., Hacker, J., and Steinert, M. (2000). Dictyostelium discoideum: a new host model system for intracellular pathogens of the genus Legionella. Cell. Microbiol. 2, 165-171. doi: 10.1046/j.1462-5822.2000.00044.x

Hohl, H. R. (1965). Nature and development of membrane systems in food vacuoles of cellular slime molds predatory upon bacteria. J. Bacteriol. 90, 755-765.

Horn, M., Fritsche, T. R., Gautom, R. K., Schleifer, K. H., and Wagner, M. (1999). Novel bacterial endosymbionts of Acanthamoeba spp. related to the Paramecium caudatum symbiont Caedibacter caryophilus. Environ. Microbiol. 1, 357-367. doi: 10.1046/j.1462-2920.1999.00045.x

Horn, M., Fritsche, T. R., Linner, T., Gautom, R. K., Harzenetter, M. D., and Wagner, M. (2002). Obligate bacterial endosymbionts of Acanthamoeba spp. related to the beta-Proteobacteria: proposal of 'Candidatus Procabacter acanthamoebae' gen. nov., sp. nov. Int. J. Syst. Evol. Microbiol. 52, 599-605. doi: 10.1099/ijs.0.01970-0

Horn, M., Harzenetter, M. D., Linner, T., Schmid, E. N., Muller, K. D., Michel, R., et al. (2001). Members of the Cytophaga-Flavobacterium-Bacteroides phylum as intracellular bacteria of acanthamoebae: proposal of 'Candidatus Amoebophilus asiaticus'. Environ. Microbiol. 3, 440-449. doi: 10.1046/j.1462-2920.2001. 00210.x

Horn, M., Wagner, M., Muller, K. D., Schmid, E. N., Fritsche, T. R., Schleifer, K. H., et al. (2000). Neochlamydia hartmannellae gen. nov., sp. nov. (Parachlamydiaceae), an endoparasite of the amoeba Hartmannella vermiformis. Microbiology 146(pt 5), 1231-1239.

Ingham, S. C., Su, Y. C., and Spangenberg, D. S. (2000). Survival of Salmonella typhimurium and Escherichia coli O157:H7 in cheese brines. Int. J. Food Microbiol. 61, 73-79. doi: 10.1016/S0168-1605(00)00331-7

Inglis, T. J., Rigby, P., Robertson, T. A., Dutton, N. S., Henderson, M., and Chang, B. J. (2000). Interaction between Burkholderia pseudomallei and Acanthamoeba species results in coiling phagocytosis, endamebic bacterial survival, and escape. Infect. Immun. 68, 1681-1686. doi: 10.1128/IAI.68.3.1681-16 86.2000

Kahane, S., Dvoskin, B., Mathias, M., and Friedman, M. G. (2001). Infection of Acanthamoeba polyphaga with Simkania negevensis and S. negevensis survival within amoebal cysts. Appl. Environ. Microbiol. 67, 4789-4795. doi: 10.1128/AEM.67.10.4789-4795.2001

Kilvington, S., and Price, J. (1990). Survival of Legionella pneumophila within cysts of Acanthamoeba polyphaga following chlorine exposure. J. Appl. Bacteriol. 68 519-525. doi: 10.1111/j.1365-2672.1990.tb02904.x

King, C. H., and Shotts, E. B. (1988). Enhancement of Edwardsiella tarda and Aeromonas salmonicida through ingestion by the ciliated protozoan Tetrahymena pyriformis. FEMS Microbiol. Lett. 51, 95-99. doi: 10.1111/j.15746968.1988.tb02976.x

King, C. H., Shotts, E. B. Jr., Wooley, R. E., and Porter, K. G. (1988). Survival of coliforms and bacterial pathogens within protozoa during chlorination. Appl. Environ. Microbiol. 54, 3023-3033.

Koubar, M., Rodier, M. H., Garduno, R. A., and Frere, J. (2011). Passage through Tetrahymena tropicalis enhances the resistance to stress and the infectivity of Legionella pneumophila. FEMS Microbiol. Lett. 325, 10-15. doi: 10.1111/j.15746968.2011.02402.x

Lamoth, F., and Greub, G. (2009). Amoebal pathogens as emerging causal agents of pneumonia. FEMS Microbiol. Rev. 34, 260-280. doi: 10.1111/j.15746976.2009.00207.x

Lamrabet, O., and Drancourt, M. (2013). Mycobacterium gilvum illustrates size-correlated relationships between Mycobacteria and Acanthamoeba polyphaga. Appl. Environ. Microbiol. 79, 1606-1611. doi: 10.1128/AEM.03 765-12

Lamrabet, O., Mba Medie, F., and Drancourt, M. (2012). Acanthamoeba polyphagaenhanced growth of Mycobacterium smegmatis. PLoS ONE 7:e29833. doi: 10.1371/journal.pone.0029833

La Scola, B., Barrassi, L., and Raoult, D. (2000). Isolation of new fastidious alpha Proteobacteria and Afipia felis from hospital water supplies by direct plating 
and amoebal co-culture procedures. FEMS Microbiol. Ecol. 34, 129-137. doi: 10.1111/j.1574-6941.2000.tb00762.x

La Scola, B., Birtles, R. J., Greub, G., Harrison, T. J., Ratcliff, R. M., and Raoult, D. (2004). Legionella drancourtii sp. nov., a strictly intracellular amoebal pathogen. Int. J. Syst. Evol. Microbiol. 54, 699-703. doi: 10.1099/ijs.0. 02455-0

La Scola, B., Mallet, M. N., Grimont, P. A., and Raoult, D. (2003). Bosea eneae sp. nov., Bosea massiliensis sp. nov. and Bosea vestrisii sp. nov., isolated from hospital water supplies, and emendation of the genus Bosea (Das et al. 1996). Int. J. Syst. Evol. Microbiol. 53, 15-20. doi: 10.1099/ijs.0.02127-0

La Scola, B., Mezi, L., Auffray, J. P., Berland, Y., and Raoult, D. (2002). Patients in the intensive care unit are exposed to amoeba-associated pathogens. Infect. Control Hosp. Epidemiol. 23, 462-465. doi: 10.1086/502086

La Scola, B., Mezi, L., Weiller, P. J., and Raoult, D. (2001). Isolation of Legionella anisa using an amoebic coculture procedure. J. Clin. Microbiol. 39, 365-366. doi: 10.1128/JCM.39.1.365-366.2001

La Scola, B., and Raoult, D. (1999). Afipia felis in hospital water supply in association with free-living amoebae. Lancet 353, 1330. doi: 10.1016/S01406736(99)00906-X

La Scola, B., and Raoult, D. (2001). Survival of Coxiella burnetii within freeliving amoeba Acanthamoeba castellanii. Clin. Microbiol. Infect. 7, 75-79. doi: 10.1046/j.1469-0691.2001.00193.x

Lienard, J., Croxatto, A., Prod'hom, G., and Greub, G. (2011). Estrella lausannensis, a new star in the Chlamydiales order. Microbes Infect. 13, 1232-1241. doi: 10.1016/j.micinf.2011.07.003

Ly, T. M. C., and Muller, H. E. (1990a). Ingested Listeria monocytogenes survive and multiply in protozoa. J. Med. Microbiol. 33, 51-54. doi: 10.1099/0022261533-1-51

Ly, T. M. C., and Muller, H. E. (1990b). Interactions of Listeria monocytogenes, Listeria seeligeri, and Listeria innocua with protozoans. J. Gen. Appl. Microbiol. 36, 143-150. doi: 10.2323/jgam.36.143

Macher, J. (1999). Bioaerosols: Assessment and Control. Cincinnati, OH: American Conference of Governmental Industrial Hygienists.

Marchetti, A., Mercanti, V., Cornillon, S., Alibaud, L., Charette, S. J., and Cosson, P. (2004). Formation of multivesicular endosomes in Dictyostelium. J. Cell Sci. 117, 6053-6059. doi: $10.1242 /$ jcs. 01524

Marciano-Cabral, F., and Cabral, G. (2003). Acanthamoeba spp. as agents of disease in humans. Clin. Microbiol. Rev. 16, 273-307. doi: 10.1128/CMR.16.2.273307.2003

Marolda, C. L., Hauroder, B., John, M. A., Michel, R., and Valvano, M. A. (1999). Intracellular survival and saprophytic growth of isolates from the Burkholderia cepacia complex in free-living amoebae. Microbiology 145(pt 7), 1509-1517. doi: 10.1099/13500872-145-7-1509

Mattei, S., Klein, G., Satre, M., and Aubry, L. (2006). Trafficking and developmental signaling: Alix at the crossroads. Eur. J. Cell Biol. 85, 925-936. doi 10.1016/j.ejcb.2006.04.002

Medie, F. M., Ben Salah, I., Henrissat, B., Raoult, D., and Drancourt, M. (2011). Mycobacterium tuberculosis complex mycobacteria as amoeba-resistant organisms. PLoS ONE 6:e20499. doi: 10.1371/journal.pone.0020499

Mercer, E. H., and Shaffer, B. M. (1960). Electron microscopy of solitary and aggregated slime mould cells. J. Biophys. Biochem. Cytol. 7, 353-356. doi: 10.1083/jcb.7.2.353

Michel, R., and Hauroder, B. (1997). Isolation of an Acanthamoeba strain with intracellular Burkholderia pickettii infection. Zentralbl. Bakteriol. 285, 541-557. doi: 10.1016/S0934-8840(97)80116-8

Michel, R., Muller, K. D., and Schmid, E. N. (1995). Ehrlichia-like organisms (Ksl(1)) observed as obligate intracellular parasites of saccamoeba species. Endocyt Cell Res 11, 69-80.

Moffat, J. F., Edelstein, P. H., Regula, D. P. Jr., Cirillo, J. D., and Tompkins, L. S. (1994). Effects of an isogenic Zn-metalloprotease-deficient mutant of Legionella pneumophila in a guinea-pig pneumonia model. Mol. Microbiol. 12, 693-705. doi: 10.1111/j.1365-2958.1994.tb01057.x

Molmeret, M., Horn, M., Wagner, M., Santic, M., and Abu Kwaik, Y. (2005). Amoebae as training grounds for intracellular bacterial pathogens. Appl. Environ. Microbiol. 71, 20-28. doi: 10.1128/AEM.71.1.20-28.2005

Neumeister, B., Reiff, G., Faigle, M., Dietz, K., Northoff, H., and Lang, F. (2000). Influence of Acanthamoeba castellanii on intracellular growth of different Legionella species in human monocytes. Appl. Environ. Microbiol. 66, 914-919. doi: 10.1128/AEM.66.3.914-919.2000
Nguyen, T. M., Ilef, D., Jarraud, S., Rouil, L., Campese, C., Che, D., et al. (2006). A community-wide outbreak of legionnaires disease linked to industrial cooling towers-how far can contaminated aerosols spread? J. Infect. Dis. 193, 102-111. doi: $10.1086 / 498575$

Nilsson, J. R. (2005). Ethanol affects endocytosis and proliferation of Tetrahymena pyriformis GL and promotes encystment. Acta Protozool. 44, 293-299.

Nygard, K., Werner-Johansen, O., Ronsen, S., Caugant, D. A., Simonsen, O., Kanestrom, A., et al. (2008). An outbreak of legionnaires disease caused by long-distance spread from an industrial air scrubber in Sarpsborg, Norway. Clin. Infect. Dis. 46, 61-69. doi: 10.1086/524016

Paquet, V. E., Lessire, R., Domergue, F., Fouillen, L., Filion, G., Sedighi, A., et al. (2013). Lipid composition of multilamellar bodies secreted by Dictyostelium discoideum reveals their amoebal origin. Eukaryot. Cell 12, 1326-1334. doi: 10.1128/EC.00107-13

Philippe, C., Blech, M. F., and Hartemann, P. (2006). Multiplication intraamibienne de Legionella pneumophila et role potentiel des amibes dans la transmission de la legionellose. Med. Mal. Infect. 36, 196-200. doi: 10.1016/j.medmal.2005.10.010

Piper, R. C., and Katzmann, D. J. (2007). Biogenesis and function of multivesicular bodies. Аnnu. Rev. Cell Dev. Biol. 23, 519-547. doi: 10.1146/annurev.cellbio.23.090506.123319

Raghu Nadhanan, R., and Thomas, C. J. (2014). Colpoda secrete viable Listeria monocytogenes within faecal pellets. Environ. Microbiol. 16, 396-404. doi: 10.1111/1462-2920.12230

Rehfuss, M. Y., Parker, C. T., and Brandl, M. T. (2011). Salmonella transcriptional signature in Tetrahymena phagosomes and role of acid tolerance in passage through the protist. ISME J. 5, 262-273. doi: 10.1038/ismej. 2010.128

Richards, A. M., Von Dwingelo, J. E., Price, C. T., and Abu Kwaik, Y. (2013). Cellular microbiology and molecular ecology of Legionella-amoeba interaction. Virulence 4, 307-314. doi: 10.4161/viru.24290

Rowbotham, T. J. (1980). Preliminary report on the pathogenicity of Legionella pneumophila for freshwater and soil amoebae. J. Clin. Pathol. 33, 1179-1183. doi: $10.1136 /$ jcp.33.12.1179

Saeed, A., Abd, H., Edvinsson, B., and Sandstrom, G. (2009). Acanthamoeba castellanii an environmental host for Shigella dysenteriae and Shigella sonnei. Arch. Microbiol. 191, 83-88. doi: 10.1007/s00203-008-0422-2

Skriwan, C., Fajardo, M., Hagele, S., Horn, M., Wagner, M., Michel, R., et al. (2002). Various bacterial pathogens and symbionts infect the amoeba Dictyostelium discoideum. Int. J. Med. Microbiol. 291, 615-624. doi: 10.1078/1438-422100177

Smith, C. D., Berk, S. G., Brandl, M. T., and Riley, L. W. (2012). Survival characteristics of diarrheagenic Escherichia coli pathotypes and Helicobacter pylori during passage through the free-living ciliate, Tetrahymena sp. FEMS Microbiol. Ecol. 82, 574-583. doi: 10.1111/j.1574-6941.2012. 01428.x

Solomon, J. M., and Isberg, R. R. (2000). Growth of Legionella pneumophila in Dictyostelium discoideum: a novel system for genetic analysis of host-pathogen interactions. Trends Microbiol. 8, 478-480. doi: 10.1016/S0966-842X(00) 01852-7

Solomon, J. M., Leung, G. S., and Isberg, R. R. (2003). Intracellular replication of Mycobacterium marinum within Dictyostelium discoideum: efficient replication in the absence of host coronin. Infect. Immun. 71, 3578-3586. doi: 10.1128/IAI.71.6.3578-3586.2003

Steinert, M., Birkness, K., White, E., Fields, B., and Quinn, F. (1998). Mycobacterium avium bacilli grow saprozoically in coculture with Acanthamoeba polyphaga and survive within cyst walls. Appl. Environ. Microbiol. 64, 2256-2261.

Thom, S., Warhurst, D., and Drasar, B. S. (1992). Association of Vibrio cholerae with fresh water amoebae. J. Med. Microbiol. 36, 303-306. doi: 10.1099/00222615-365-303

Thomas, V., Herrera-Rimann, K., Blanc, D. S., and Greub, G. (2006). Biodiversity of amoebae and amoeba-resisting bacteria in a hospital water network. Appl. Environ. Microbiol. 72, 2428-2438. doi: 10.1128/AEM.72.4.2428-24 38.2006

Tomov, A. T., Tsvetkova, E. D., Tomova, I. A., Michailova, L. I., and Kassovski, V. K. (1999). Persistence and multiplication of obligate anaerobe bacteria in amebae under aerobic conditions. Anaerobe 5, 19-23. doi: 10.1006/anae.19 99.0182 
Verhoeven, A. B., Durham-Colleran, M. W., Pierson, T., Boswell, W. T., and Van Hoek, M. L. (2010). Francisella philomiragia biofilm formation and interaction with the aquatic protist Acanthamoeba castellanii. Biol. Bull. 219, $178-188$.

Winiecka-Krusnell, J., Wreiber, K., Von Euler, A., Engstrand, L., and Linder, E. (2002). Free-living amoebae promote growth and survival of Helicobacter pylori. Scand. J. Infect. Dis. 34, 253-256. doi: 10.1080/003655401100 80052

Conflict of Interest Statement: The authors declare that the research was conducted in the absence of any commercial or financial relationships that could be construed as a potential conflict of interest.
Received: 24 February 2014; accepted: 02 May 2014; published online: 21 May 2014. Citation: Denoncourt AM, Paquet VE and Charette SJ (2014) Potential role of bacteria packaging by protozoa in the persistence and transmission of pathogenic bacteria. Front. Microbiol. 5:240. doi: 10.3389/fmicb.2014.00240

This article was submitted to Microbial Physiology and Metabolism, a section of the journal Frontiers in Microbiology.

Copyright (C) 2014 Denoncourt, Paquet and Charette. This is an open-access article distributed under the terms of the Creative Commons Attribution License (CC BY). The use, distribution or reproduction in other forums is permitted, provided the original author(s) or licensor are credited and that the original publication in this journal is cited, in accordance with accepted academic practice. No use, distribution or reproduction is permitted which does not comply with these terms. 